\title{
Laboratory measurement of strength mobilisation in kaolin: link to stress history
}

\author{
P. J. VARDANEGA*, B. H. LAU*, S. Y. LAM*, S. K. HAIGH*, S. P. G. MADABHUSHI* and M. D. BOLTON*
}

This letter presents data from triaxial tests conducted as part of a research programme into the stress-strain behaviour of clays and silts at Cambridge University. To support findings from earlier research using databases of soil tests, eighteen $\mathrm{CIU}$ triaxial tests on speswhite kaolin were performed to confirm an assumed link between mobilisation strain $\left(\gamma_{M=2}\right)$ and overconsolidation ratio (OCR). In the moderate shear stress range $\left(0 \cdot 2 c_{\mathrm{u}}\right.$ to $\left.0 \cdot 8 c_{\mathrm{u}}\right)$ the test data are essentially linear on log-log plots. Both the slopes and intercepts of these lines are simple functions of OCR.

KEYWORDS: deformation; laboratory tests; plasticity; shear strength; stiffness

ICE Publishing: all rights reserved

\section{NOTATION}

A regression coefficient

$b \quad$ exponent determined from regression analysis

CIU consolidated isotropic undrained

$c_{\mathrm{u}} \quad$ undrained shear strength

$c_{\mathrm{u}} \quad$ consolidated isotropic undrained

$d \quad$ exponent determined from regression analysis

$e_{0} \quad$ initial void ratio

$G \quad$ shear modulus

$G_{0} \quad$ maximum shear modulus

$I_{\mathrm{p}} \quad$ plasticity index

$M \quad$ mobilisation factor $c_{\mathrm{u}} / \tau_{\mathrm{mob}}$

$m \quad$ exponent determined from regression analysis

$n$ number of data points used to generate a correlation

OCR overconsolidation ratio

$p \quad$ the smallest level of significance that would lead to the rejection of the null hypothesis, i.e. that the value of $r=0$, in the case of determining the $p$-value for a regression atmospheric pressure

$p_{\mathrm{c}}^{\prime} \quad$ maximum effective consolidation pressure

$p_{0}^{\prime} \quad$ mean stress in the triaxial after swell back

$q \quad$ deviator stress

$R^{2} \quad$ coefficient of determination of a correlation (the square of the correlation coefficient $r$ )

$S \quad$ regression coefficient

SE standard error in a regression, a quantification of deviation about the fitted line

$w_{\mathrm{L}} \quad$ liquid limit

$\gamma \quad$ shear strain, taken as 1.5 times the axial strain $\left(\varepsilon_{\mathrm{a}}\right)$ in this letter

$\gamma_{M=2}$ mobilisation strain

$\varepsilon_{\mathrm{a}} \quad$ axial strain

$\kappa \quad$ slope of unload-reload line

$\Lambda \quad$ exponent in the equation of Ladd et al. (1977)

$\lambda \quad$ slope of normal compression line

$\sigma_{\mathrm{v} 0}^{\prime} \quad$ vertical effective stress in the ground

$\sigma_{\mathrm{vc}}^{\prime} \quad$ maximum past effective vertical stress in the ground

$\tau_{\mathrm{mob}} \quad$ mobilised shear stress

\section{INTRODUCTION}

Knowledge of soil stiffness and stress-strain behaviour is essential to the calculation of ground displacements that

Manuscript received 19 January 2012; first decision 13

February 2012; accepted 9 March 2012

Published online at www.geotechniqueletters.com on 30 March 2012.

${ }^{*}$ Department of Engineering, University of Cambridge, Cambridge, UK may damage structures. These serviceability considerations, termed SLS in Eurocode 7 (BSI, 2010), should be at the forefront of the geotechnical practitioner's mind. For example, deformations are important in the design of offshore wind turbines, both in terms of dynamic structural response under severe loads and due to the vulnerability of the drive and gearbox to tilting of the mast.

Research has been undertaken at Cambridge University to define and validate simplified mechanistic models in conjunction with soil stress-strain data to enable routine calculations of footing settlements (Osman \& Bolton, 2005; Osman et al., 2007) and the displacement of braced retaining structures (Osman \& Bolton, 2006; Lam \& Bolton, 2011), for example. The calculation procedure is based on conservation of energy and is known as mobilisable strength design (MSD).

An important feature of MSD is the need to model the strength mobilisation of the soil. The shear stiffness of clays and silts at small strains has been shown to be empirically determinable using the maximum shear modulus $\left(G_{0}\right)$ and a quasi-hyperbolic stress-strain relation in which the shear strain required to halve the stiffness was seen to vary with the liquid limit $\left(w_{\mathrm{L}}\right)$ (Vardanega \& Bolton, 2011a). This letter presents measurements of stress versus strain for kaolin clay for various stress histories and for stress levels approaching failure, in undrained CIU triaxial compression tests. A summary of the basic kaolin parameters from the present study is shown in Table 1.

Previous investigations into the stiffness of reconstituted soils are detailed by Houlsby \& Wroth (1991) and Viggiani \& Atkinson (1995). Viggiani \& Atkinson (1995) fitted equation (1) to laboratory data of the initial shear modulus for a range of clays, including kaolin

$$
\frac{G_{0}}{p_{\mathrm{a}}}=S\left(\frac{p_{0}^{\prime}}{p_{\mathrm{a}}}\right)^{d} \mathrm{OCR}^{m}
$$

where $G_{0}$ is the maximum shear modulus, $p_{\mathrm{a}}$ is atmospheric pressure, $p_{0}^{\prime}$ is mean stress $(\mathrm{kPa})$, OCR is the overconsolidation ratio (defined as either $p_{\mathrm{c}}^{\prime} / p_{0}^{\prime}$ or as $\sigma_{\mathrm{vc}}^{\prime} / \sigma_{\mathrm{v} 0}^{\prime}$ ) and $d, m$ and $S$ are experimentally determined coefficients. Equation (1) shows the degree of overconsolidation to be a key determinant in the prediction of the small-strain stiffness of soils. The relation between degree of overconsolidation and behaviour at larger strain levels is the focus of this letter. 
Table 1. Summary of basic properties of the tested kaolin (numbers in square brackets indicate the number of tests to determine the parameter)

\begin{tabular}{l|c}
\hline Plastic limit $w_{\mathrm{P}}: \%$ & $29 \cdot 6[4]$ \\
Liquid limit $w_{\mathrm{L}}: \%$ & $62 \cdot 6[1]$ \\
Slope of normal compression line $\lambda$ & $0 \cdot 250[4]$ \\
Slope of unload-reload line $\kappa$ & $0 \cdot 039[6]$ \\
\hline
\end{tabular}

\section{EXPERIMENTAL METHODOLOGY}

During triaxial compression, the axial stress is increased while keeping the cell pressure constant. An undrained test maintains constant volume, allowing excess pore pressures to develop. Conventional triaxial testing methodology is outlined in Bishop and Henkel (1957).

In the triaxial tests, an external linear variable differential transformer (LVDT) measures the overall movement of the sample (used to capture the strain data) to an accuracy of $0 \cdot 125 \mathrm{~mm}$. A strain accuracy of $10^{-3}$ is sufficient to capture the influence of the OCR on the moderate stress region (defined in the next section), which is the aim of this letter.

Details of the effective stress history of the triaxial tests performed are displayed in Table 2, where $p_{\mathrm{c}}^{\prime}$ is the maximum effective consolidation pressure, $p_{0}^{\prime}$ is the mean effective stress after swelling back and OCR denotes the ratio between the two. A backpressure of $350 \mathrm{kPa}$ was maintained during the tests.

\section{STRESS-STRAIN BEHAVIOUR}

Figure 1 shows the stress-strain curves measured in the eighteen CIU triaxial tests, four of which were reported by $\mathrm{Xu}$ (2011). The data are plotted on $\log -\log$ axes. The range of OCR studied is from 1 to 20 . The data are presented in terms of shear strain $\gamma$ in the triaxial test, which is taken in this letter as

$$
\gamma=1 \cdot 5 \varepsilon_{\mathrm{a}}
$$

This is done on the premise that (e.g. Terzaghi et al., 1996)

$$
\begin{aligned}
& \frac{\gamma}{2}=\frac{\varepsilon_{1}-\varepsilon_{3}}{2} \\
& \varepsilon_{3}=\frac{-\varepsilon_{1}}{2}
\end{aligned}
$$

where $\varepsilon_{1}$ and $\varepsilon_{3}$ are the principal strains.

Table 2. Stress history of triaxial tests performed

\begin{tabular}{l|c|c|c}
\hline Test ID & $p_{c}^{\prime}: \mathrm{kPa}$ & $p_{0}^{\prime}: \mathrm{kPa}$ & OCR \\
\hline $180(1)$ & 180 & 180 & 1 \\
$180(2)$ & 180 & 90 & 2 \\
$180(5)$ & 180 & 36 & 5 \\
$180(10)$ & 180 & 18 & 10 \\
$180(20)$ & 180 & 9 & 20 \\
$300(2)$ & 300 & 150 & 2 \\
$300(5)$ & 300 & 60 & 5 \\
$300(10)$ & 300 & 30 & 10 \\
$300(15)$ & 300 & 20 & 15 \\
300(20) & 300 & 15 & 20 \\
500(2) & 500 & 250 & 2 \\
500(10) & 500 & 50 & 10 \\
500(15) & 500 & $33 \cdot 3$ & 15 \\
500(20) & 500 & 25 & 20 \\
500(1)_Xu & 500 & 500 & 1 \\
500(2)_Xu & 500 & 250 & 2 \\
500(5)_Xu & 500 & 100 & 5 \\
500(10)_Xu & 500 & 50 & 10 \\
\hline
\end{tabular}

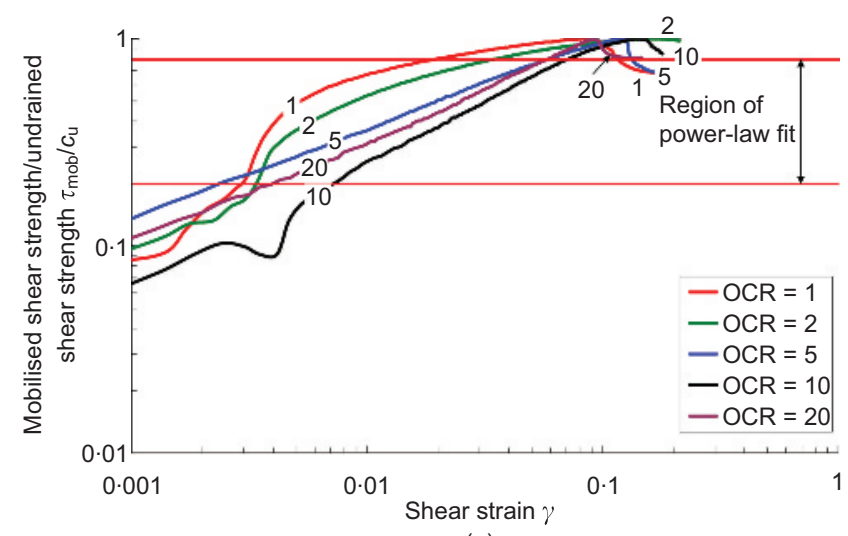

(a)

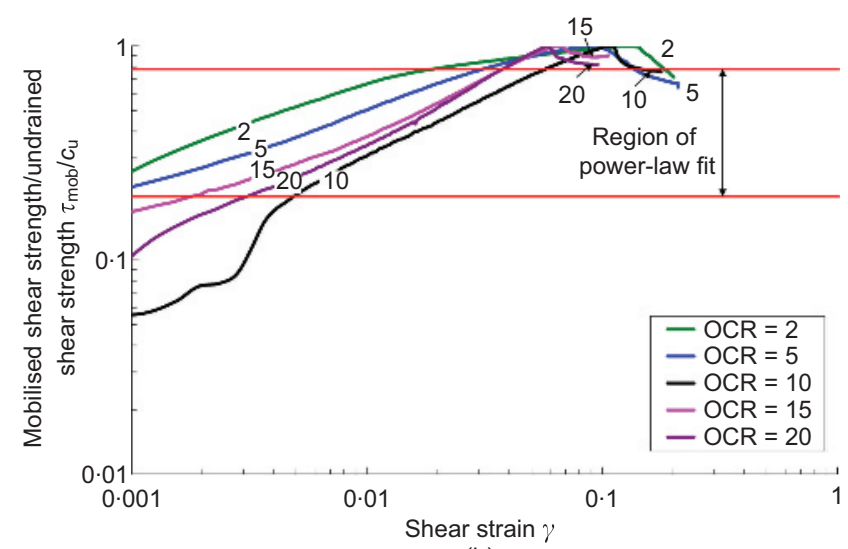

(b)

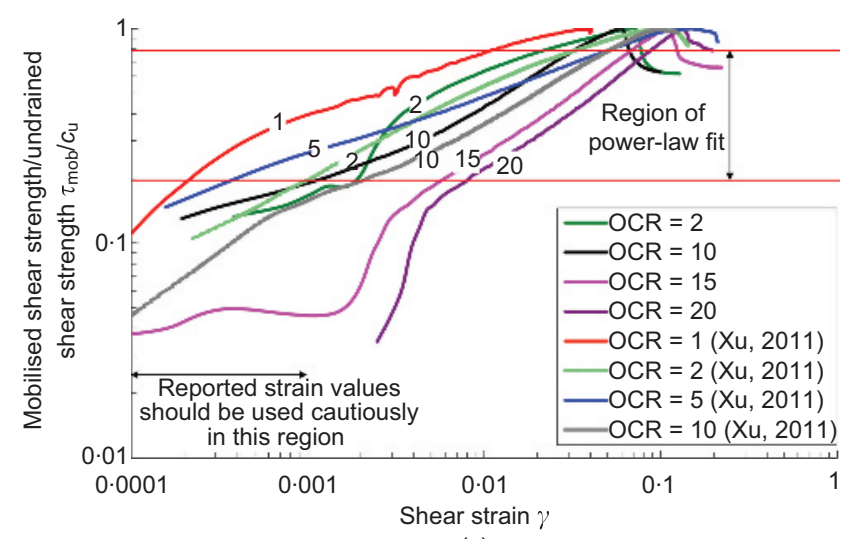

(c)

Fig. 1. Triaxial test data for tests with (a) $180 \mathrm{kPa}$ preconsolidation, (b) $300 \mathrm{kPa}$ pre-consolidation and (c) $500 \mathrm{kPa}$ pre-consolidation

The stress-strain curves from triaxial testing are sensibly linear over a range of moderate stresses when the data are plotted on $\log -\log$ axes.

Verification of $c_{\mathrm{u}}$ values at varying stress levels

The undrained shear strength ratio $\left(c_{\mathrm{u}} / \sigma_{\mathrm{v} 0}^{\prime}\right)_{\mathrm{nc}}$ for normally consolidated soils can be estimated from Skempton's correlation $(1954,1957)$

$$
\left(c_{\mathrm{u}} / \sigma_{\mathrm{v} 0}^{\prime}\right)_{\mathrm{nc}}=0 \cdot 11+0 \cdot 37 I_{\mathrm{p}}
$$

From Table 1, the plasticity index $I_{\mathrm{p}}$ for the clay tested in the present study is $0 \cdot 33$. Using equation (4), this gives an empirical value of $\left(c_{\mathrm{u}} / \sigma_{\mathrm{v} 0}^{\prime}\right)_{\mathrm{nc}}=0 \cdot 23$, which corresponds reasonably well with the average of the test values of $\left(c_{\mathrm{u}} / p_{0}^{\prime}\right)_{\mathrm{nc}}$ of $0 \cdot 19\left(\right.$ at $\left.p_{\mathrm{c}}^{\prime}=500 \mathrm{kPa}\right)$ and $0 \cdot 29\left(\right.$ at $p_{\mathrm{c}}^{\prime}=180$ $\mathrm{kPa}$ ); see Table 3. Equation (5) gives the relationship for 
Table 3. Curve-fitting and normalisation parameters

\begin{tabular}{|c|c|c|c|c|c|c|c|}
\hline Test ID & $A$ & $b$ & $R^{2}$ & $n$ & $c_{\mathrm{u}}: \mathrm{kPa}$ & $e_{0}$ & $\gamma_{M=2}$ \\
\hline $180(1)$ & $5 \cdot 861$ & $0 \cdot 484$ & $0 \cdot 850$ & 59 & $51 \cdot 7$ & $1 \cdot 15$ & $0 \cdot 00521$ \\
\hline $180(2)$ & $3 \cdot 531$ & 0.425 & 0.938 & 79 & $38 \cdot 4$ & $1 \cdot 27$ & $0 \cdot 00880$ \\
\hline $180(5)$ & $2 \cdot 825$ & $0 \cdot 443$ & 0.999 & 102 & $32 \cdot 0$ & $1 \cdot 12$ & $0 \cdot 01969$ \\
\hline $180(10)$ & $3 \cdot 882$ & 0.595 & 1.000 & 115 & $19 \cdot 9$ & $1 \cdot 29$ & 0.03201 \\
\hline $180(20)$ & $3 \cdot 572$ & $0 \cdot 530$ & 0.999 & 139 & $15 \cdot 9$ & $1 \cdot 21$ & 0.02506 \\
\hline $300(2)$ & $3 \cdot 311$ & $0 \cdot 356$ & $0 \cdot 980$ & 52 & $68 \cdot 6$ & $1 \cdot 23$ & $0 \cdot 00445$ \\
\hline $300(5)$ & $3 \cdot 034$ & 0.389 & 0.998 & 110 & $45 \cdot 6$ & $1 \cdot 17$ & 0.00988 \\
\hline $300(10)$ & $3 \cdot 681$ & $0 \cdot 540$ & $1 \cdot 000$ & 140 & $30 \cdot 6$ & $1 \cdot 21$ & $0 \cdot 02488$ \\
\hline $300(15)$ & $3 \cdot 733$ & 0.489 & 0.991 & 194 & $34 \cdot 2$ & 1.08 & 0.01737 \\
\hline $300(20)$ & $5 \cdot 082$ & $0 \cdot 580$ & 0.995 & 131 & $27 \cdot 5$ & $1 \cdot 19$ & $0 \cdot 01924$ \\
\hline $500(2)$ & $4 \cdot 227$ & $0 \cdot 423$ & 0.926 & 50 & $105 \cdot 1$ & $1 \cdot 13$ & $0 \cdot 00530$ \\
\hline $500(10)$ & $3 \cdot 732$ & $0 \cdot 460$ & 0.991 & 131 & $57 \cdot 5$ & $1 \cdot 18$ & $0 \cdot 01337$ \\
\hline $500(15)$ & $3 \cdot 750$ & $0 \cdot 584$ & $0 \cdot 998$ & 159 & $36 \cdot 4$ & $1 \cdot 14$ & $0 \cdot 03265$ \\
\hline $500(20)$ & $3 \cdot 350$ & 0.602 & 0.997 & 200 & $32 \cdot 8$ & $1 \cdot 20$ & 0.04389 \\
\hline 500(1)_Xu & $3 \cdot 236$ & $0 \cdot 311$ & $0 \cdot 987$ & 45 & $93 \cdot 4$ & $\mathrm{n} / \mathrm{a}$ & $0 \cdot 00261$ \\
\hline $500(2) \_\mathrm{Xu}$ & 2.972 & $0 \cdot 377$ & 0.991 & 96 & $88 \cdot 1$ & $\mathrm{n} / \mathrm{a}$ & $0 \cdot 00815$ \\
\hline 500(5)_Xu & $1 \cdot 879$ & $0 \cdot 291$ & 0.998 & 96 & $69 \cdot 7$ & $\mathrm{n} / \mathrm{a}$ & $0 \cdot 01121$ \\
\hline $500(10) \_X u$ & $3 \cdot 192$ & $0 \cdot 470$ & 0.998 & 133 & $56 \cdot 0$ & $\mathrm{n} / \mathrm{a}$ & 0.01978 \\
\hline
\end{tabular}

overconsolidated soils taken from Ladd et al. (1977); in Fig. 2 it is fitted to the triaxial tests data, taking $\left(c_{\mathrm{u}} / p_{0}^{\prime}\right)_{\mathrm{nc}}$ as $0 \cdot 23$. While not identical, the use of $c_{\mathrm{u}} / p_{0}^{\prime}$ and $c_{\mathrm{u}} / \sigma_{\mathrm{v} 0}^{\prime}$ interchangeably in Ladd's equation (as has been done in Fig. 2) was explored by Muir Wood (1990) who concluded that no significant difference results.

$$
\frac{c_{\mathrm{u}} / \sigma_{\mathrm{v} 0}^{\prime}}{\left(c_{\mathrm{u}} / \sigma_{\mathrm{v} 0}^{\prime}\right)_{\mathrm{nc}}}=\mathrm{OCR}^{\Lambda}
$$

where $\sigma_{\mathrm{v} 0}^{\prime}$ is the vertical effective stress, OCR is the overconsolidation ratio defined as $\sigma_{\mathrm{vc}}^{\prime} / \sigma_{\mathrm{v} 0}^{\prime}$ and $\Lambda$ is an empirical exponent, which may decrease with increasing OCR (Ladd et al., 1977; Muir Wood, 1990) from 0.85 to $0 \cdot 75$; nc denotes normal consolidation.

From critical state soil mechanics (Schofield and Wroth, 1968), Muir Wood (1990) showed that $\Lambda$ should be given by

$$
\Lambda=\frac{\lambda-\kappa}{\lambda}
$$

Based on data collected by Mayne (1980) and presented by Muir Wood (1990), $\Lambda$ varies between $0 \cdot 2$ and 1.0 with a mean value of 0.63 and a standard deviation of $0 \cdot 18$. This is a significantly greater range than would be implied by equation (5).

Using the values from Table 1 in equation (6), it would be expected that $\Lambda=0 \cdot 84$, although Muir Wood cautions that it is difficult to determine a reliable value of $\kappa$ from the mean slope of a swelling line. From Fig. 2, the value of $\Lambda$ is shown to be 0.68 (when the regression is forced through the origin, as implied by equation (5)), which is slightly lower than the theoretical value; however, it is similar to the mean of previously collected experimental data (Mayne, 1980).

The general form of Ladd's relationship is shown to fit the test data well. This allows one to conclude that the $c_{\mathrm{u}}$ values computed from the test data are not unreasonable.

\section{Mobilisation strain framework}

A recent review of strength mobilisation in clays and silts (Vardanega and Bolton, 2011b) presented a large database of 115 tests on natural samples of 19 clays compiled from a range of publications. It was shown that a power law fits the moderate stress region $\left(0 \cdot 2<\tau_{\mathrm{mob}} / c_{\mathrm{u}}<0 \cdot 8\right)$ of the stressstrain curves very well. The power law has the following elementary form (Vardanega \& Bolton, 2011b)

$$
\tau_{\mathrm{mob}} / c_{\mathrm{u}}=A \gamma^{b}
$$

In the previously published database, $b$ for the 115 tests in the database was shown to range from 0.3 to 1.2 with an average of $0 \cdot 6$.

\section{Analysis of new kaolin data}

Figure 3 shows power curves fitted to the 18 triaxial tests on reconstituted kaolin. It is observed that power curves do not fit the test data as well at low OCRs as they do at moderate to high OCRs. Figure 4 shows that the $b$ value from equation (7) is related to the OCR via the following regression equation

$$
b=0 \cdot 011(\mathrm{OCR})+0 \cdot 371
$$

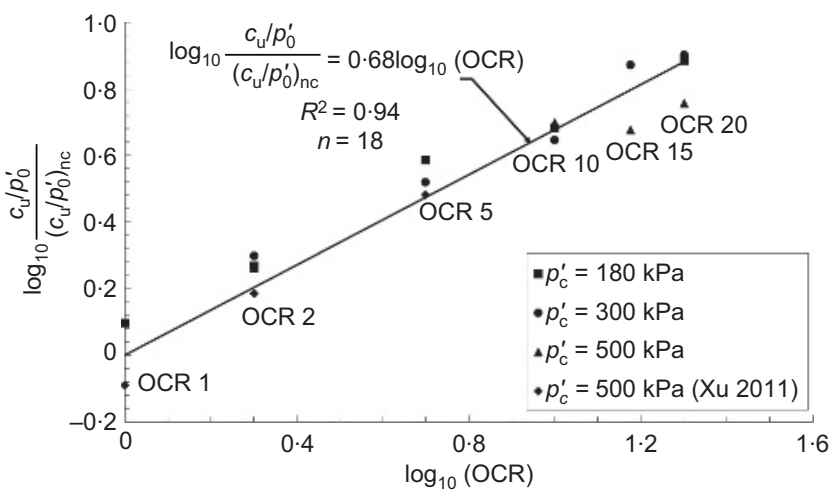

Fig. 2. Fitting the equation of Ladd et al. (1977) equation to the test data 


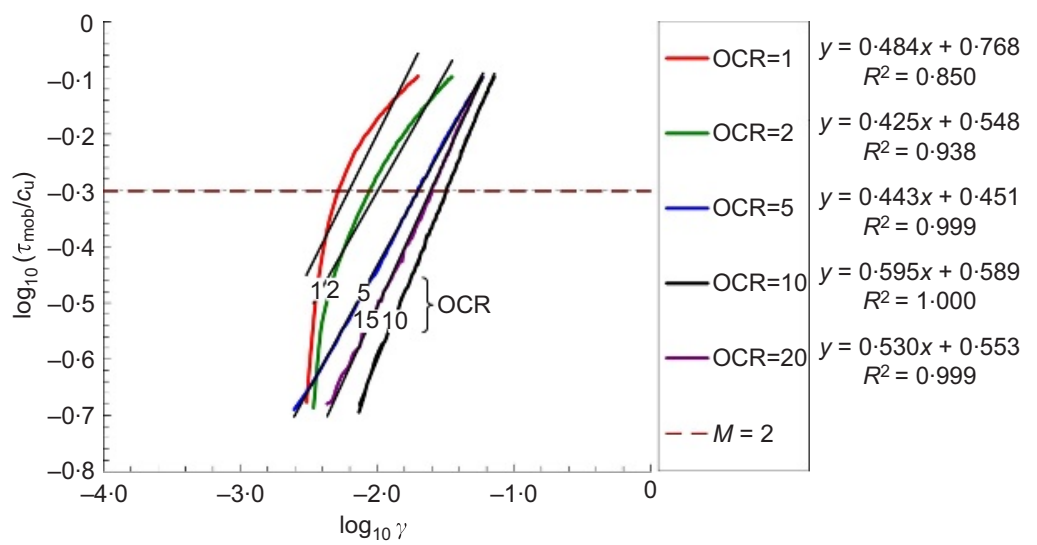

(a)

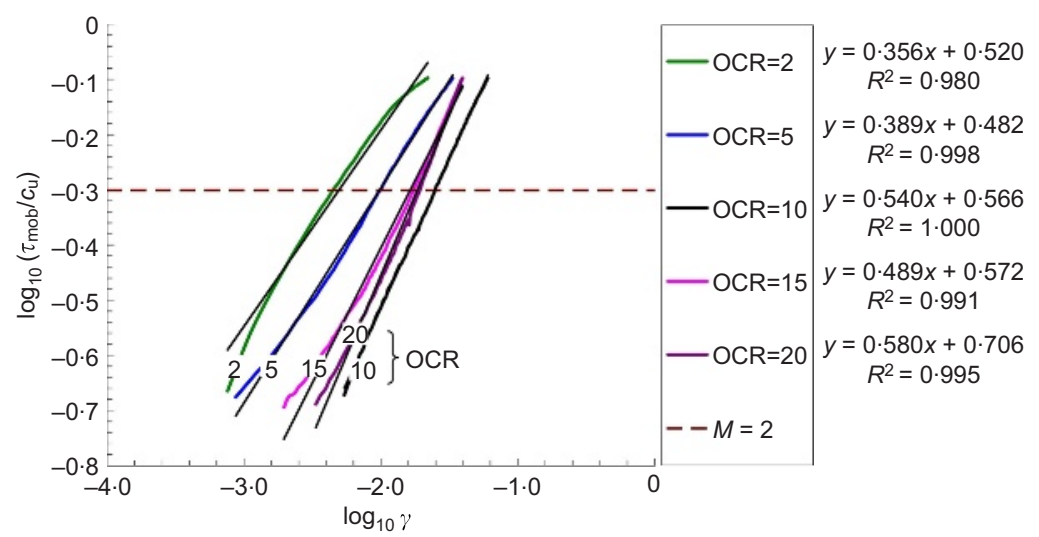

(b)

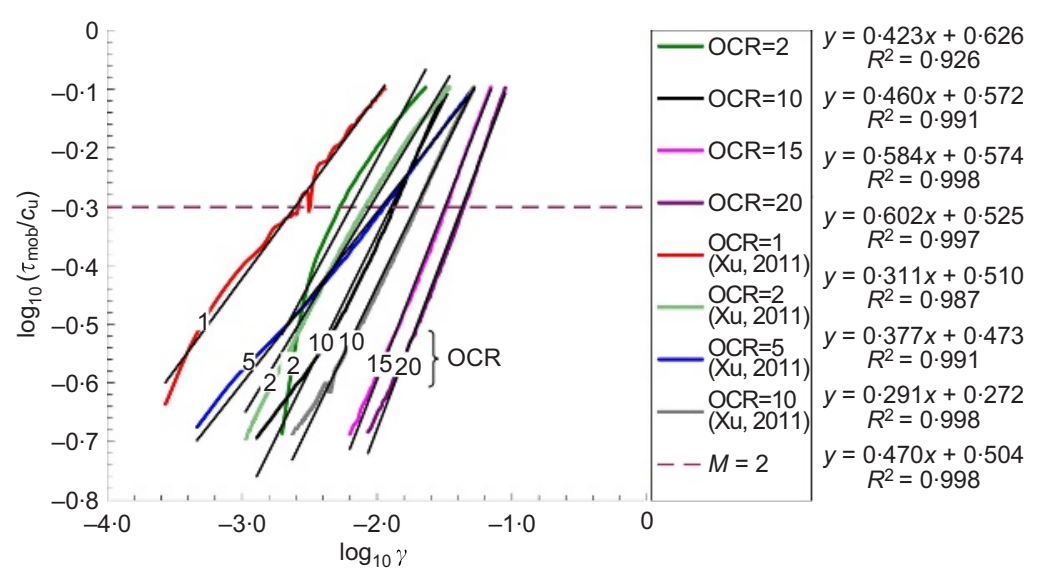

(c)

Fig. 3. Fitting power curves to the test data: (a) $180 \mathrm{kPa}$ data (five tests); (b) $300 \mathrm{kPa}$ data (five tests); (c) $500 \mathrm{kPa}$ data (eight tests)

for which $R^{2}=0 \cdot 591, n=18, \mathrm{SE}=0 \cdot 064$ and $p<0 \cdot 001$.

The mobilisation strain is the magnitude of shear strain at which half the shear strength is mobilised (Vardanega \& Bolton, 2011b), hence

$$
\left(\gamma_{M=2}\right)=\left(\frac{0 \cdot 5}{A}\right)^{1 / b}
$$

Table 3 lists the values of the curve-fitting parameters $A$ and $b$ together with measured values of undrained shear strength $c_{\mathrm{u}}$ and mobilisation strain $\gamma_{M=2}$ for the 18 tests on kaolin. The undrained shear strength is used to normalise the shear stress and the mobilisation strain is used to normalise the shear strain. The resulting prediction equation for shear strength mobilisation has the form

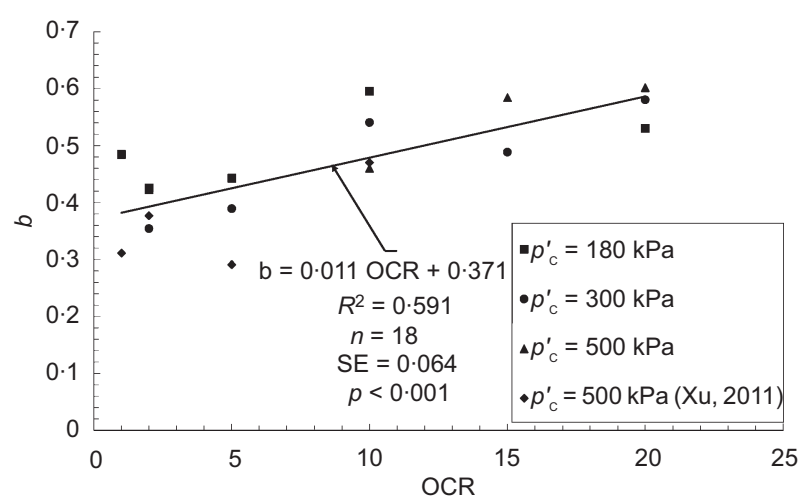

Fig. 4. $b$ versus OCR 


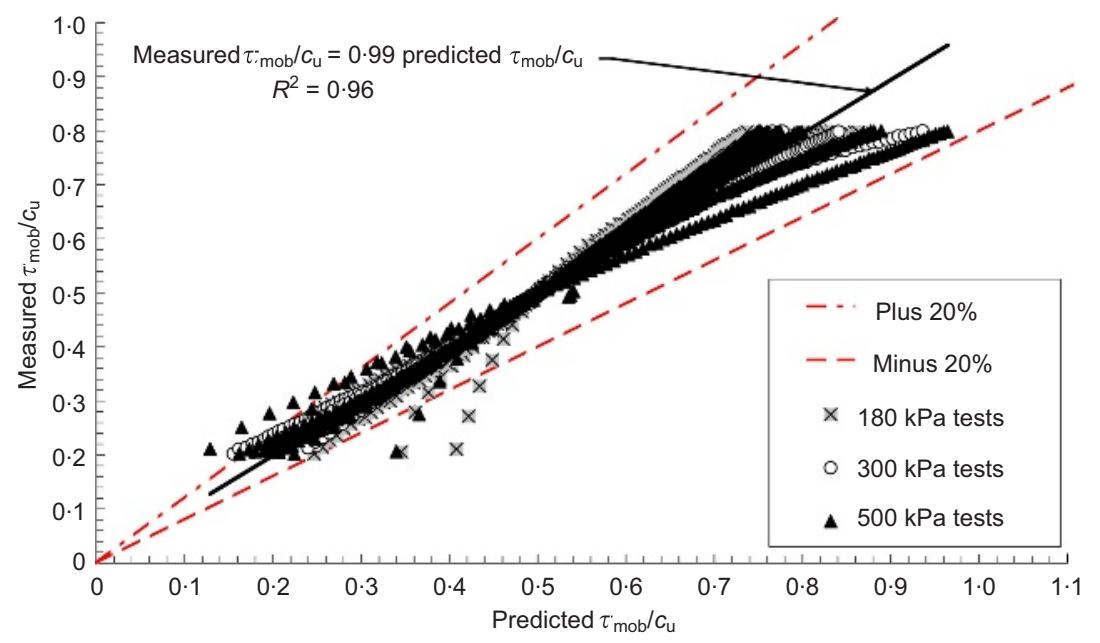

Fig. 5. Predicted versus measured $\tau_{\mathrm{mob}} / c_{\mathrm{u}}$ using equations (8) and (10)

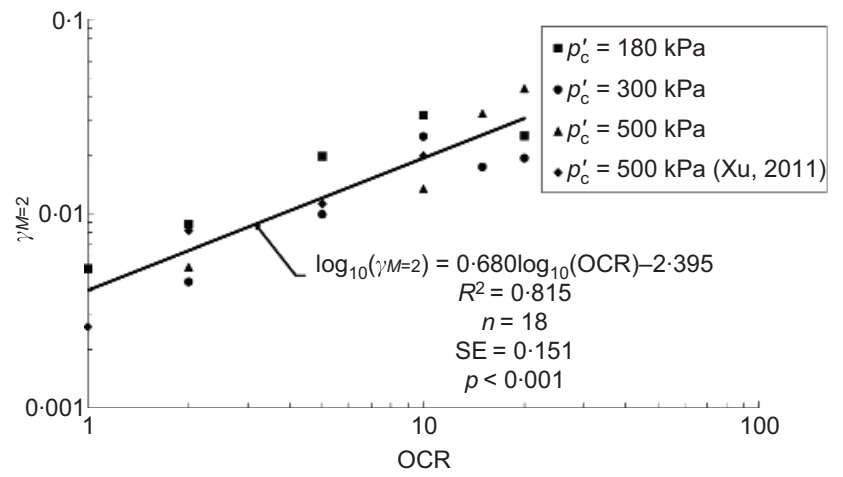

Fig. 6. Logarithm of mobilisation strain versus logarithm of OCR

$$
\tau_{\text {mob }} / c_{\mathrm{u}}=0 \cdot 5\left(\frac{\gamma}{\gamma_{M=2}}\right)^{b}
$$

in the range $0 \cdot 2<\tau_{\mathrm{mob}} / c_{\mathrm{u}}<0 \cdot 8$

Figure 5 shows a plot of $\tau_{\mathrm{mob}} / c_{\mathrm{u}}$ as predicted using equation (8) for the exponent and equation (10) for the mobilised shear strength ratio, versus corresponding measurements. The $R^{2}$ on the plot is 0.96 and the slope is very close to $1 \cdot 0(0 \cdot 99)$, which validates the use of the two equations in tandem. This level of accuracy is only attained if the mobilisation strain $\left(\gamma_{M=2}\right)$ is known precisely.

\section{INFLUENCE OF STRESS HISTORY ON MOBILISATION STRAIN}

Vardanega \& Bolton (2011c) showed that the mobilisation strain is related to depth of sample for a database of tests on natural London clay samples. The observation of $\gamma_{M=2}$ increasing with decreasing depth is akin to suggesting that $\gamma_{M=2}$ increases with OCR. Figure 6 shows the mobilisation strain $\gamma_{M=2}$ plotted against OCR. A good coefficient of determination is observed $\left(R^{2}=0 \cdot 815\right)$ and the $p$-value is very small $(<0 \cdot 001)$. For kaolin, the following regression relationship is available

$$
\log _{10}\left(\gamma_{M=2}\right)=0.680 \log _{10}(\mathrm{OCR})-2.395
$$

for which $R^{2}=0 \cdot 815, n=18, \mathrm{SE}=0 \cdot 151$ and $p<0 \cdot 001$. Rearranging equation (11) gives

$$
\left(\gamma_{M=2}\right)=0 \cdot 0040(\mathrm{OCR})^{0 \cdot 680}
$$

Figure 7 shows the predicted versus measured plot when equations (8), (10) and (12) are used to predict $\tau_{\mathrm{mob}} / c_{\mathrm{u}}$. The error bands widen to around $\pm 40 \%$ due to the scatter about the trend line in Fig. 6. Using equations (8), (10) and

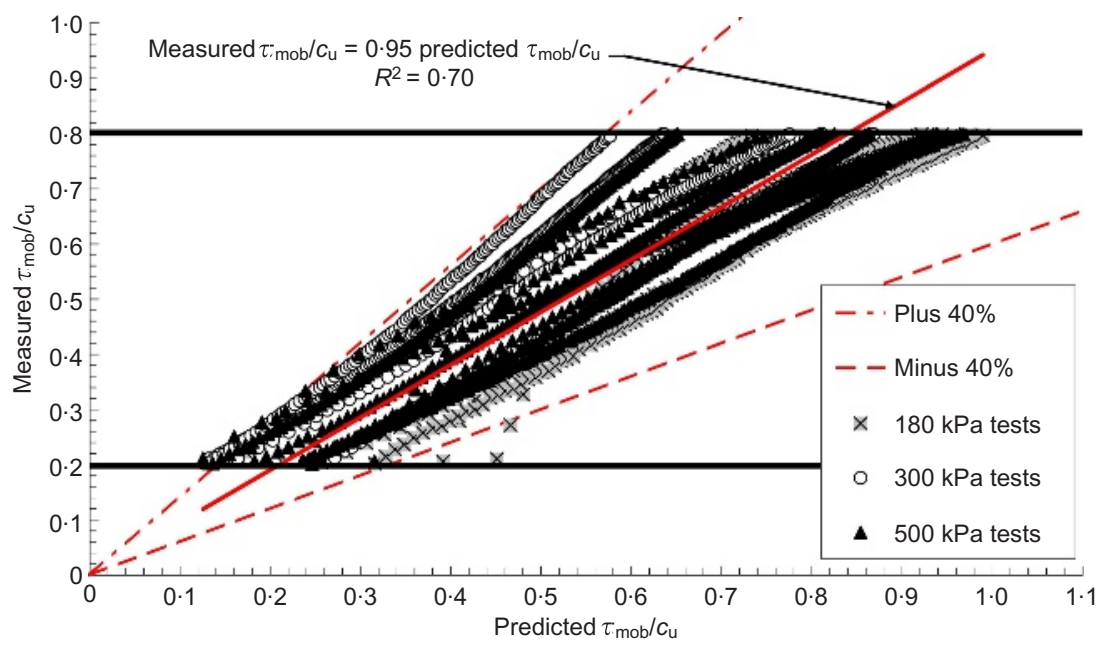

Fig. 7. Measured versus predicted $\tau_{\mathrm{mob}} / c_{\mathrm{u}}$ using equations (8), (10) and (12) 


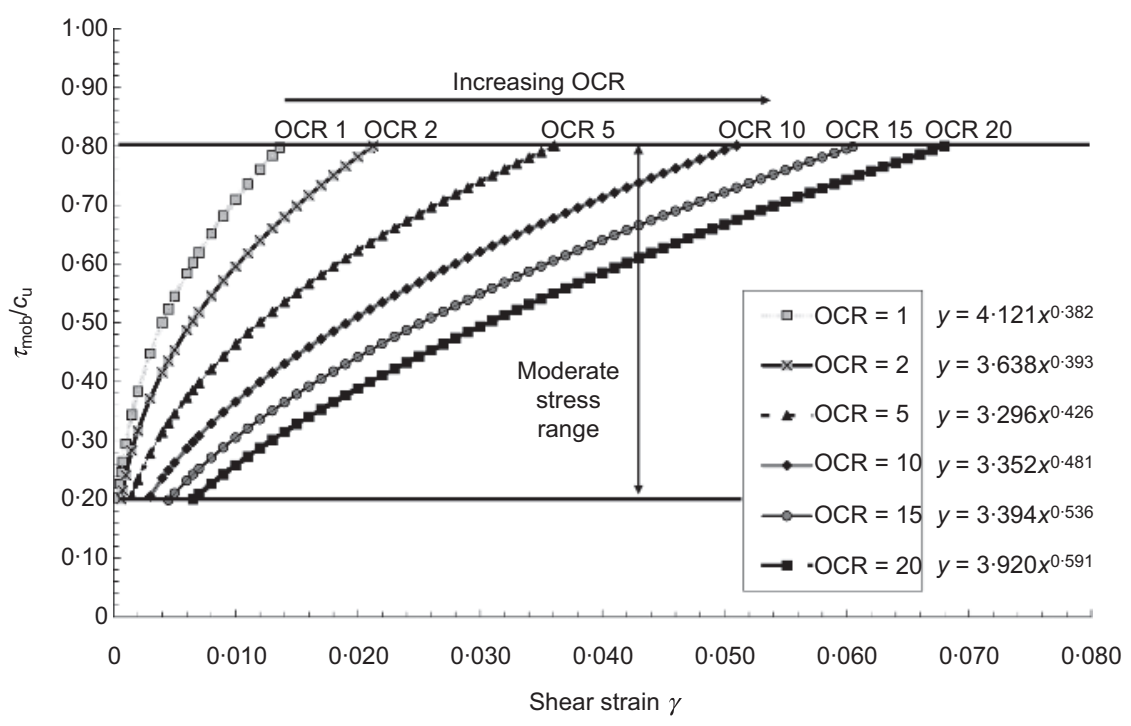

Fig. 8. General stress-strain curves drawn using equations (8), (10) and (12)

(12), the predicted stress-strain curves are drawn in Fig. 8. Similar behaviour is shown in the data of Todi clay presented by Burland et al. (1996) and analysed in Vardanega \& Bolton (2011b).

\section{Implications for design}

The implication for geotechnical design is that less strain is needed to mobilise the same proportion of shear strength the deeper a geotechnical structure is built. For a bored pile in overconsolidated clay, for example, the soil in contact with the shaft at the top of the pile is likely to be significantly more compliant than the soil in contact with the base.

If the pile head settlement at working load is to be calculated using a $t-z$ analysis, one must make assumptions about the variation of $t-z$ spring behaviour with depth. If a designer assigns a single value of $G / c_{\mathrm{u}}$ for the soil, this implies a single strain to failure at all depths. This letter has shown that such an assumption would be unwarranted.

\section{SUMMARY AND CONCLUSIONS}

This letter has focused on establishing a link between mobilisation strain and stress history. The following summary points and conclusions are made.

1. Data from $18 \mathrm{CIU}$ triaxial tests on reconstituted kaolin samples confirm that the stress-strain curves (in the moderate stress region) are roughly linear on $\log -\log$ plots.

2. The mobilisation strain framework presented by Vardanega \& Bolton (2011b, 2011c) is verified for reconstituted kaolin. A simple stress-strain model for kaolin is

$\tau_{\mathrm{mob}} / c_{\mathrm{u}}=0 \cdot 5\left(\frac{\gamma}{\gamma_{M=2}}\right)^{b}$ in the range $0 \cdot 2<\tau_{\mathrm{mob}} / c_{\mathrm{u}}<0 \cdot 8$

where $b=0 \cdot 011(\mathrm{OCR})+0 \cdot 371$. The average exponent $b$ recorded by Vardanega \& Bolton (2011b), for natural clays of unknown OCR, was 0.6 within a range of $0 \cdot 3-1 \cdot 2$. This is not inconsistent with the current data of these tests on reconstituted kaolin.

3. The mobilisation strain $\gamma_{M=2}$ is shown to increase strongly with the logarithm of overconsolidation ratio via the following relationship for kaolin
$\gamma_{M=2}=0 \cdot 0040(\mathrm{OCR})^{0 \cdot 680}$

4. Just as OCR has been previously found (equation (1)) to influence small-strain stiffness, so it has now been demonstrated to influence both the position and slope of stress-strain curves of clay in the region of moderate strength mobilisations, when plotted on $\log -\log$ axes.

\section{ACKNOWLEDGEMENTS}

Thanks are due to $\mathrm{Mr}$ Chris Knight for his technical services, to Miss $\mathrm{X}$. $\mathrm{Xu}$ (former MEng student at Cambridge University) for providing her triaxial data for analysis, to the Cambridge Commonwealth Trust and Ove Arup and Partners for their financial support of the first author, and to the EPSRC for financial support from grant $\mathrm{EP} / \mathrm{H} 013857 / 1$ 'Cyclic behaviour of monopile foundations for offshore windfarms'.

\section{REFERENCES}

Bishop, A. W. \& Henkel, D. J. (1957). The measurement of soil properties in the triaxial test, 2 nd edn. London: Edwin Arnold.

BSI (2010). Eurocode 7: BS EN 1997-1-2004: Geotechnical design - Part I: General Rules. BSI, Milton Keynes, UK (incorporating corrigenda February 2009).

Burland, J. B., Rampello, S., Georgiannou, V. N. \& Calabresi, G. (1996). A laboratory study of the strength of four stiff clays. Géotechnique 46, No. 3, 491-514.

Houlsby, G. T. \& Wroth, C. P. (1991). The variation of shear modulus of a clay with pressure and overconsolidation ratio. Soils and Found. 31, No. 3, 138-145.

Ladd, C., Foot, R., Ishihara, K., Schlosser, F. \& Poulos, H. (1977). Stress-deformation and strength characteristics. Proc. 9th Int. Conf. Soil Mech. and Found. Engng, Tokyo 2, 421-494.

Lam, S. Y. \& Bolton, M. D. (2011). Energy conservation as a principle underlying mobilizable strength design for deep excavations. J. Geotech. Geoenviron. Engng ASCE 137, No. $11,1062-1074$.

Mayne, P. W. (1980). Cam-Clay predictions of undrained strength. J. Geotech. Engng Div. ASCE 106 No. 11, 1219-1242.

Muir Wood, D. (1990). Soil behaviour and critical state soil mechanics. Cambridge: Cambridge University Press.

Osman, A. S. \& Bolton, M. D. (2005). Simple plasticity-based prediction of the undrained settlement of shallow circular foundations on clay. Géotechnique 55, No. 6, 435-447. 
Osman, A. S. \& Bolton, M. D. (2006). Ground movement predictions for braced excavations in undrained clay. $J$. Geotech. Geoenviron. Engng ASCE 132, No. 4, 465-477.

Osman, A. S., White, D. J., Britto, A. M. \& Bolton, M. D. (2007). Simple prediction of the undrained displacement of a circular surface foundation on non-linear soil. Géotechnique 57, No. 9, $729-737$.

Schofield, A. N. \& Wroth, C. P. (1968). Critical state soil mechanics. London: McGraw-Hill.

Skempton, A. W. (1954). Discussion: sensitivity of clays and the c/p ratio in normally consolidated clays. Proc. Am. Soc. Civil Eng. Separate 478, 19-22.

Skempton, A. W. (1957). Discussion: further data on the $\mathrm{c} / \mathrm{p}$ ratio in normally consolidated clays. Proc. Inst. Civil Eng. 7, 305-307.

Terzaghi, K., Peck, R. B. and Mesri, G. (1996). Soil mechanics in engineering practice, 3rd edn. New York: John Wiley \& Sons.
Vardanega, P. J. \& Bolton, M. D. (2011a). Practical methods to estimate the non-linear shear stiffness of clays and silts. Proc. 5th Int. Symp. Deformation Characteristics of Geomaterials, Seoul, 1-3 September 2011. Hanrimwon Co. Ltd, vol. 1, pp. 372-379.

Vardanega, P. J. \& Bolton, M. D. (2011b). Strength mobilization in clays and silts. Canadian Geotech. J. 48, No. 10, 14851503.

Vardanega, P. J. \& Bolton, M. D. (2011c). Predicted shear strength mobilization of London clay. Proc. 15th Euro. Conf. Soil Mech. and Geotech. Engng, Athens, 12-15 September 2011. IOS Press, vol. 1, pp. 487-492.

Viggiani, G. and Atkinson, J. H. (1995). Stiffness of fine-grained soil at very small strains. Géotechnique 45, No. 2, 249-265.

$\mathrm{Xu}, \mathrm{X}$. (2011). The small strain stiffness of clay. MEng thesis, University of Cambridge.

\section{WHAT DO YOU THINK?}

To discuss this paper, please email up to 500 words to the editor at journals@ice.org.uk. Your contribution will be forwarded to the author(s) for a reply and, if considered appropriate by the editorial panel, will be published as a discussion. 